\section{International Journal of

DOI: 10.31695/IJASRE.2019.33402
E-ISSN : 2454-8006

Volume 5, Issue 7

July - 2019

\title{
Perspective and Prospect of Tidal Electricity Generation in Iraq
}

\author{
Ahmed N Ahmed Hamdan, Abdulhussain A Abbas \& Khalid Al-Asadi \\ Department of Civil Engineering \\ College of Engineering \\ University of Basrah, Basrah, Iraq
}

\begin{abstract}
For a long time, Iraq has been suffering from the environmental pollution and electricity crisis. Therefore, tidal energy is one of the best renewable sources should be used to solve together the environmental pollution and electricity crisis. Tidal energy is usually available in coastal areas. Southern of Iraq has coastal areas in Basra Governorate on the northern Arabian Gulf. Therefore, this study has been investigated the possibility of establishing tidal power stations in two locations in Basra, Um Qasr and Al-Faw. In the case of the construction of a $4 \mathrm{~km}^{2}$ tidal barrage in Um Qasr, the electricity generated was $98.85 \mathrm{MW}$ and 197.69MW to meet the demand for electricity in Basra by $6.59 \%$ and $13.18 \%$ in the case of one-way and two-way generation, respectively. While in case of construction of a $4 \mathrm{~km}^{2}$ tidal lagoon in Al-Faw, the electricity generated was $31.37 M W$ and $62.73 \mathrm{MW}$ to meet the demand for electricity in Basra by $2.09 \%$ and $4.18 \%$ in the case of one-way and two way generation, respectively. So, this study clearly shows that tidal energy can contribute significantly to relief the electricity crisis in Basra Governorate.
\end{abstract}

Key Words: Electricity Crisis, Mathematical Modeling, Probability Density Function, Tidal Lagoon, Tidal Power.

\section{INTRODUCTION}

Iraq is developed country with population more than 37 million in 2017 [1]. Demand electricity is growing at a rate higher than the rate of electricity production so that the demand for energy cannot yet meet the entire country. Currently in 2017 , Power generated from all Iraqi national power plants and imported energy was almost $15,000 \mathrm{MW}$ while the demand was almost 19,000 MW. Therefore, Power deficit was almost 4,000MW and the maximum power deficit was 6,000MW during peak electricity consumption in July Which caused programmed cutting of electricity between 6 to 9 hours/day [2,3]. The Iraqi government should make quick decisions and plans to address the recurring electricity crisis by reducing the use of conventional energy sources and encouraging the use of renewable energy. Most conventional energy plants are use fossil fuel (Gas, Coal, Oil etc.) to produce electricity which causing pollution to the environment as well as increasing the cost of electricity production due to high fossil fuel prices [4]. Most of the countries of world suffer from environmental pollution and energy crisis, which are the two most important issues could be solved together through use of renewable energy [5].

Tidal energy is one of the forms of renewable energy that used in the world, in particular for coastal regions [6]. It has many advantages over solar and wind energy. Tidal energy has many advantages over other forms of renewable energy like very environment friendly, Predictable, Effective at Low Speeds, Long Life spans and ineffective of climate [7]. Iraq has a coastline measuring 58km (36 miles) on the northern Arabian Gulf [8]. Therefore, the tidal power plant is one of the available solutions to relief the electricity crisis in Iraq and meeting up our power demand as well as minimizing environmental pollution. However, there is no research that has been conducted yet where the coastal engineering infrastructure is already present. So, our government should give their attention into the field of tidal power as soon as possible.

However, in 1966, the world's first and second large-scale tidal power plant was situated at the estuary of the Rance River in St. Malo, France. This ocean tidal power station still operates today, producing 240MWh of power each year. [9] The world's bigge st tidal power station with an output capacity of 254MW is located on Lake Sihwa in South Korea. [10] The other tidal power stations are Swansea bay tidal lagoon in United Kingdom (240MW), MeyGen tidal energy project in Scotland (86MW), Annapolis Royal Generating Station in Canada (20MW) etc. [11] 
This paper focuses on the exploration of the potential tidal power in the coastal area of Basra Governorate in south of Iraq, especially in the two sites were Um Qasr and Al-Faw. The statistical analysis of the tides for these sites will be conducted to determine the highest flood tide and lowest ebb tide to determine the tidal range. Then, derive a mathematical model to prediction the potential tidal and electric power for these two sites. Finally, the main aim of this paper is to determine the ratio of power generation from these tidal power station to relief some of the energy crisis of Iraq.

\section{MATERIALS AND METHODS}

\subsection{Study Area}

Spot selection is the first step to construct a tidal power generation plant. Coastal areas are rich by tidal energy due to available the high tidal range and high tide waves. The amount of tide power depends on the tidal range which is equal to the high tides minus low tides. Iraq has a coastline measuring $58 \mathrm{~km}$ (36 miles) on the northern Arabian Gulf [8]. The dominant type of tide in coastal areas of Iraq is semidiurnal tides because of repeated flood and ebb tides twice every day. Coastal areas in Iraq have a tidal range between 2-5m [12]. Therefore, these areas have a sufficient tidal power to be converted into electricity. The coastal areas of Iraq are located only in Basra Governorate, southern of Iraq. So, the study area was included the coastal areas in Basra Governorate to investigate the possibility of generating electricity from tidal power as shown in Fig. 1. There are two possible sites for the production of electricity from the tidal power were identified in Basra Governorate (in southern Iraq) as follows:

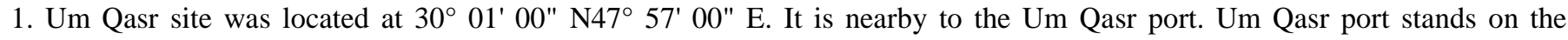
canalised Khawr Al-Zubayr, part of the Khawr Abd Allah which leads to the Arabian Gulf.Authors and affiliations

2. Al-Faw site was located at $29^{\circ} 49^{\prime} 60^{\prime \prime} \mathrm{N} 48^{\circ} 43^{\prime} 00^{\prime \prime}$ E. It is nearby to the Shatt Al Arab river estuary which leads to the Arabian Gulf.

Those spots were investigated for suitability to construct a tidal power plant as well as produce enough electricity from tidal range. The tidal data of Um Qasr and Al-Faw point has been collected from TIDES4FISHING and SOLUNAR [13].

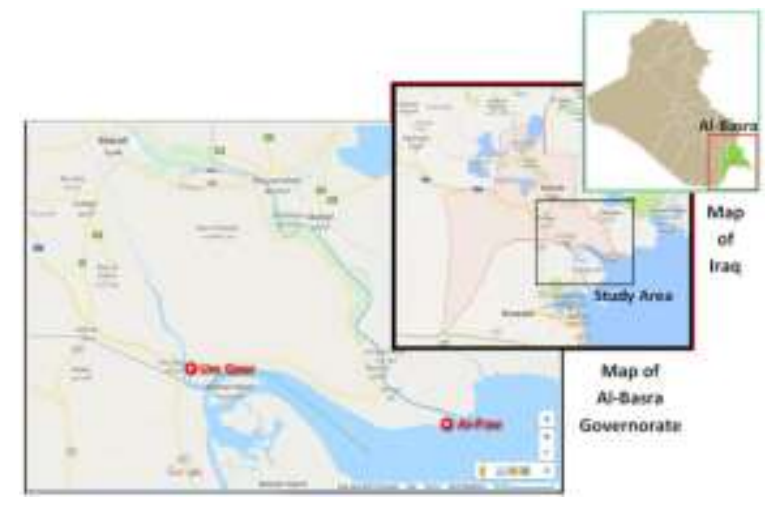

\subsection{Types of Tides}

Figure 1: Location of Um Qasr and Al-Faw in the Study Area

Tides are the periodic raising and lowering of average sea level that occurs throughout the ocean. Tides are the rise and fall of sea levels caused by the combined effects of the gravitational forces exerted by the Moon and the Sun and the water inertia or centrifugal force due to the rotation of the Earth [14]. The Sun's gravity is stronger than the Moon's, but the Sun is also 400 times farther than the Moon. So the lunar tides are more than twice as strong as the solar tides [15]. Unlike a 24-hour solar day, a lunar day lasts 24 hours and 50 minutes. This occurs because the moon revolves around the Earth in the same direction that the Earth is rotating on its axis. Therefore, it takes the Earth an extra 50 minutes to "catch up" to the moon [16]. As shown in Fig. 2, when Earth, Moon, and Sun align at full Moon and new Moon the gravity of the Moon and Sun combine to create higher high tides and lower low tides, known as "spring" tides. But when the Moon is at first or last quarter, the Moon and Sun are pulling at right angles to each other, so high tides are lower than average, while low tides are higher a phase known as "neap" tide making every tide a little different from all the others. Ebb is the tidal phase during which the water level is falling and flood the tidal phase during which the water level is rising [17]. Tidal range the difference in height between consecutive high and low waters. The tidal range varies from a maximum during spring tides to a minimum during neap tides. The tidal range is not constant but changes depending on the locations of the sun and the moon.

Based on the number of high and low tides and their relative heights each tidal day, tides are described as semi-diurnal, mixed, or diurnal. Figure 3 shows the tidal curves for these three common types of tides. The tide is said to be diurnal when only one high and one low tide every lunar day with a tidal period is lasting about 24 hours and 50 minutes [18]. Semidiurnal is characterized by two equal high and two equal low tides per lunar day with a tidal period is lasting about 12 hours and 25 minutes. Tides along the Coast of Iraq are semidiurnal [19]. Whereas, a mixed tide is a tidal cycle which contains two unequal high tides and two unequal low tides [20]. 


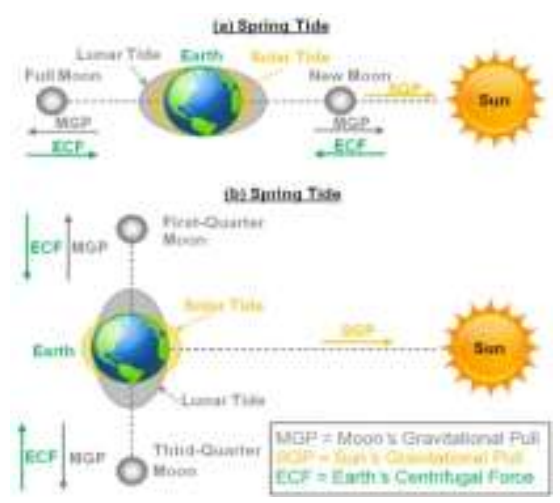

Figure 2: Effect of Earth-Moon-Sun positions on Production of Ocean-tides.

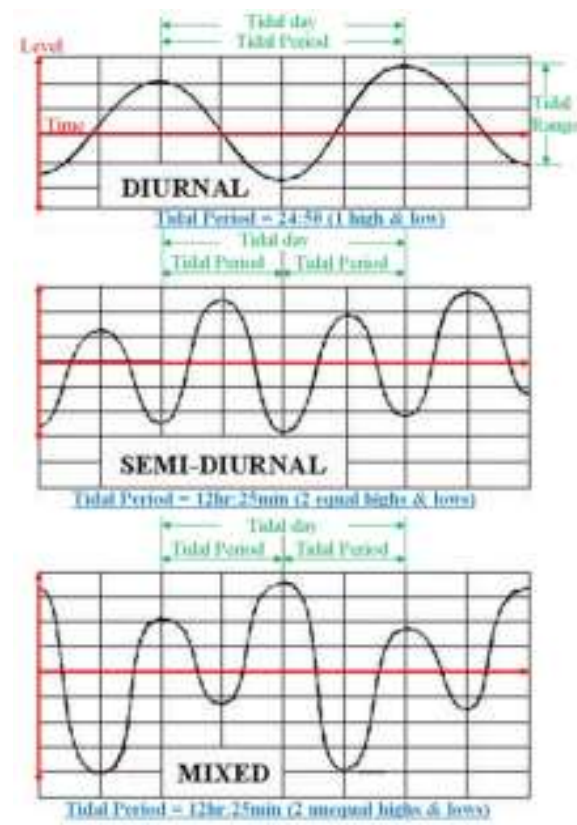

Figure 3: Common Types of Ocean-Tides.

\subsection{Probability Density Function}

The calculation of tidal range depends on the highest high and lowest low tide. Therefore it is necessary to perform a statistical analysis to find out the probability of the prevailing high and low tide by translating the probability density function (PDF) of the high and low tide using MATLAB [21].

\subsection{Tidal Power Mathematical Model}

Tidal power or tidal energy is a form of hydropower that converts the energy obtained from the vertical or horizontal movement of tides into useful forms of power, mainly electricity. So, Utilization of tidal energy can be classified into two main types [22]:

1. Tidal Barrages or lagoon, is extract the electricity power from the vertical movement of water due to flood and ebb tides in sea or ocean.

2. Tidal Current Turbines is extract the electricity power from the horizontal water movement due to the movement of sea or ocean waves.

This study deals only with Tidal Barrage. A tidal barrage is a dam-like structure installed across an inlet of an ocean bay or lagoon that forms a tidal basin as shown in Fig. 4. Sluice gates on the barrage control water levels and flow rates to allow the tidal basin to fill on the incoming high tides and to empty through an electricity turbine system on the outgoing ebb tide.

Figure 4 shows a single basin and a single effect tidal power scheme. It is the case of basin beginning at high-tide level, emptying through the turbine to sea, which is at 'low tide'; head (y) varying from (R) to $(0)$. The symbols used to derive the equation of potential energy (and then power) that available from a tidal barrage were as below:

$\mathrm{R}=$ Tidal range,

$\mathrm{A}=$ Basin surface area, considered constant, $\mathrm{m}^{2}$,

$\rho=$ Density of water, $1025 \mathrm{~kg} / \mathrm{m}^{3}$,

$\mathrm{g}=$ Gravitational constant, $9.81 \mathrm{~m} / \mathrm{s}^{2}$

$\mathrm{m}=$ Mass of water flowing through the turbine, $\mathrm{kg}$,

$\mathrm{h}=$ Head, $\mathrm{m}$, and 
$\mathrm{W}=$ Work done by water flowing through turbine (in Joule, $\mathrm{J}$ ).

For tidal range (R), and certain head (y) at the given time during the flow from the sea to basin, the differential work done (dW) is equal to the force (Weight of water $=\mathrm{g} \times \mathrm{dm}$ ) multiplied by the height lost $(\mathrm{y})$.

Hence, $\mathrm{dW}=\mathrm{g} \times \mathrm{dm} \times \mathrm{y}$

But, $\mathrm{dm}=\rho \times \mathrm{A} \times \mathrm{dy}$

So, that $\mathrm{dW}=\rho \times \mathrm{g} \times \mathrm{A} \times \mathrm{dy} \times \mathrm{y}$

The total work done $(\mathrm{W})$ by water while emptying the basin is obtained by integrating $\mathrm{dW}$ from 0 to $\mathrm{R}$,

$$
\begin{gathered}
W=\int_{0}^{n} \rho g A y d y=\rho g A \int_{0}^{\pi} y d y=\frac{1}{2} \rho g A[y]_{0}^{R} \\
W=\frac{1}{2} \rho g A R^{2}
\end{gathered}
$$

Thus, Eq. (2) indicates that work is proportional to square of the tidal range (R).

Since, the power is the rate of doing work. So, the power is generated during emptying (or filling) and no power is generated during rest of the time.

$$
\text { Tidal power, } T P=\frac{\text { Work done, } W}{\text { Time }, T}
$$

Substituting Eq. (2) in Eq. (3) to get the following

$$
T P=\frac{\rho g A R^{2}}{2 T}=\frac{1025 \times 9.81 \times A R^{2}}{2 T}=5027.625 \frac{A R^{2}}{T}
$$

In case of semidiurnal tide which is the prevailing case on Iraqi marine water,

The tidal period $=1 / 2$ lunar day $=1 / 2 \times 24 \mathrm{hr} 50 \mathrm{~min}=12 \mathrm{~h} 25 \mathrm{~min}=44,700 \mathrm{sec}$

For a single tide, $\mathrm{T}=0.50$ tidal period $=22,350 \mathrm{sec}$

$$
\begin{aligned}
& T P=5027.625 \frac{A R^{2}}{T}=5027.625 \frac{A R^{2}}{22350}=0.225 A R^{2} \\
& \text { and, Power Density, } T P_{D}=\frac{T P}{A}=0.225 R^{2}\left(\frac{W}{m^{2}} \text { or } \frac{M W}{k^{2}}\right)
\end{aligned}
$$

So, for four tides (semidiurnal tide: two ebb \& two flood tide)

$$
\begin{gathered}
T P=4 \times 0.225 A R^{2}=0.9 A R^{2} \\
T P_{D}=0.9 R^{2}
\end{gathered}
$$

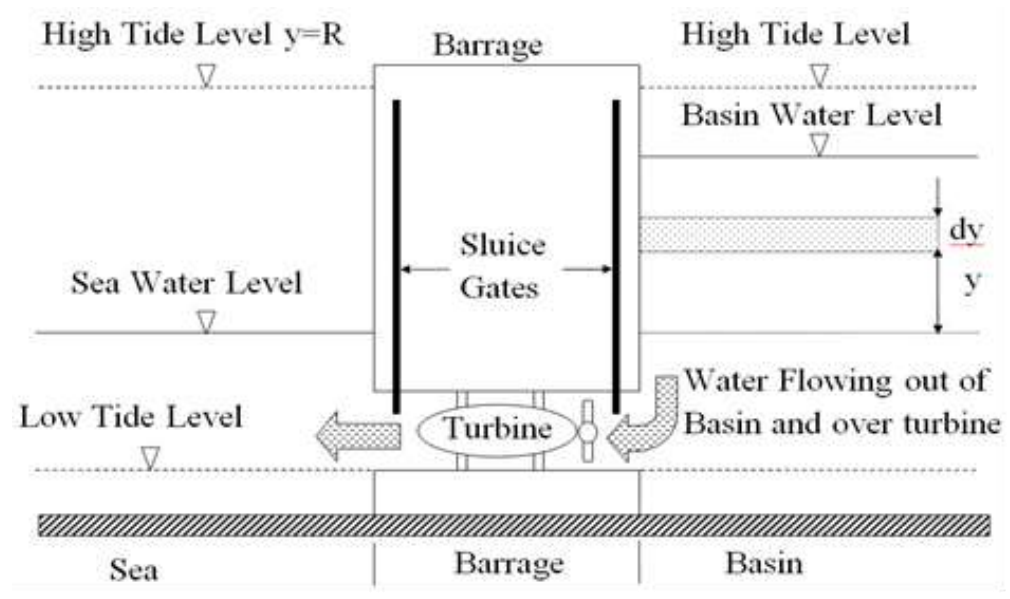

Figure 4: Derivation of power formula for tidal barrage operation. 


\subsection{Electricity Power Generation}

Tidal barrage (or lagoon) can use various electric power generation schemes: one way generation (ebb or flood generation) and two-way generation. The three main tidal energy barrage schemes that use water levels differential on both sides of barrage to generate electricity by turbines are as follow [23]:

- Ebb Generation: in which the tidal power is generated as the water leaves the tidal reservoir on the ebb tide. A full ebb generation cycle consists of four stages are filling basin, holding, ebb generating and holding once again as shown in Fig. 5.

- Flood Generation: in which the tidal power is generated as the water enters the tidal reservoir on the incoming tide A full flood generation cycle consists of four stages are emptying basin, holding, flood generating and holding once again as shown in Fig. 6.

- Two-way Generation: in which the tidal power is generated as the water flows in both directions during a flood and ebb tide. A full ebb generation cycle consists of four stages are flood generating, holding, ebb generating and holding once again as shown in Fig. 7.

While, the operating stages are defined as follow [24]:

- Sluicing: Open sluice gate to fill basin during flood tide or empty basin during ebb tide.

- Holding: Close the sluice gate to hold the water in the basin until the falling tide creates sufficient head for generation.

- Ebb generating: Empty the basin through turbines to generate electricity until minimum operating head is reached.

- Flood generating: Fill the basin through turbines to generate electricity until minimum operating head is reached.

In this part of the paper it will deal with the calculation of the potential tidal power density of Um Qasr and Al-Faw to investigate the best site for construction a tidal power station to generate electricity. Eq. (9) will be used in the next analysis because of the prevailing situation in the coastal area of Basra is semidiurnal tide.

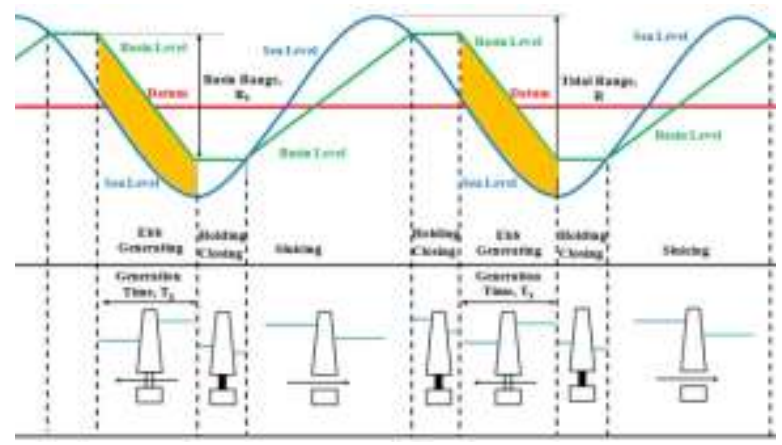

Figure 5: Schematization of water levels and stages for One-way ebb generation.

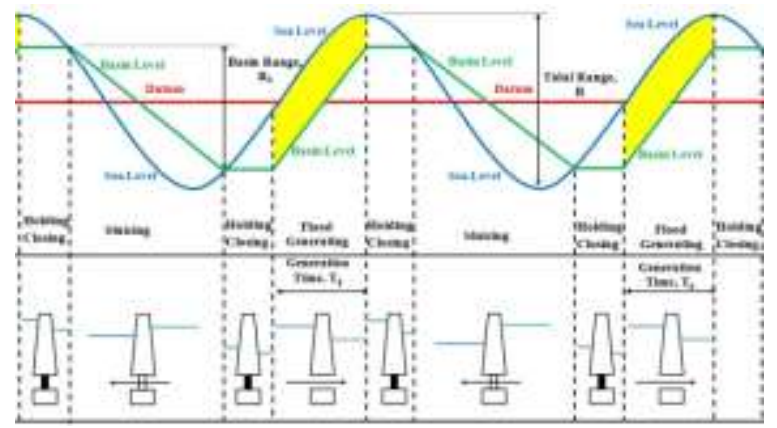

Figure 6: Schematization of water levels and stages for One-way flood generation.

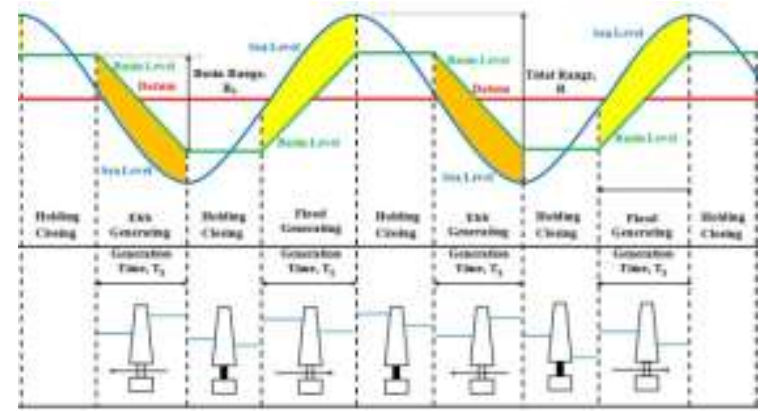

Figure 7: Schematization of water levels and stages for Two-way.

\subsection{Mathematical modelling of Electricity Power}

In this part of the paper, the electrical power (EP) that could be generated from one-way or two-way turbines was estimated at Um Qasr and Al-Faw site. 
In general,

$$
\mathrm{EP}=\mathrm{E} \times \mathrm{TP} \times \mathrm{N}
$$

Where,

$\mathrm{EP}=$ Electricity Power

$\mathrm{N}=$ number of turbine

$\mathrm{E}=$ Turbine efficiency

TP = Tidal Energy was calculated from Eq. (4) and substituted in Eq. (9), the equation become as below:

$$
E P=5027.625 \frac{E N A R^{2}}{T}
$$

Replacement $\mathrm{R}$ by $\mathrm{R}_{\mathrm{b}}$ and $\mathrm{T}$ by $\mathrm{T}_{\mathrm{g}}$, the equation become as below:

$$
E P=5027.625 \frac{N E A R_{b}^{2}}{T_{g}}
$$

Where,

$\mathrm{R}_{\mathrm{b}}=$ water level range in basin $(\mathrm{m})=\mathrm{HWL}-\mathrm{h}_{\text {min }}$

$\mathrm{HWL}=$ Average high tide throughout the year

$\mathrm{h}_{\min }=$ Minimum head over turbine which was consider as 0.28R [25]

$\mathrm{T}=$ tidal period, for case of semidiurnal tide,

$\mathrm{T}=1 / 2$ lunar day $=1 / 2 \times 24 \mathrm{hr} 50 \mathrm{~min}=12 \mathrm{~h} 25 \mathrm{~min}=44,700 \mathrm{sec}$

$\mathrm{T}_{\mathrm{g}}=$ generation time (s) which was consider as 0.33T [26]

So, $\mathrm{T}_{\mathrm{g}}=0.33 \times 44,700=14751 \mathrm{sec}$

$\mathrm{E}=$ Turbine efficiency.

There are friction losses, conversion efficiencies of the turbine and generator that reduce the power. Turbine efficiency usually varying among 20-40\%. Mostly proposed a value of 33\% for turbine efficiency to estimate the generating electricity power [27]. Substituting the values of $\mathrm{T}$ and $\mathrm{E}$ in Eq. (10). So, the equation for electric power generation from one ebb tide (single tide) will become as below

$$
E P=0.1125 N A R_{b}^{2}
$$

The equation to calculate the number of turbine $(\mathrm{N})$ was derived from the continuity equation as follows Volume of water discharged outside basin $=$ change in volume of water inside basin

$$
\begin{gathered}
N Q T_{g}=A R_{b} \\
N=\frac{A R_{b}}{Q T_{g}}
\end{gathered}
$$

Where,

$\mathrm{Q}=$ flow rate of turbine. The suitable type of turbine for lower water head is Bevel Gear Bulb (BGB) turbine which has a flow rate of $45 \mathrm{~m}^{3} / \mathrm{s}$ and its required $28 \%$ of tidal range $(0.28 \mathrm{R})$ as minimum head to operate [8].

So, the equation 13 will become as below:

$$
\therefore N_{T}=1.5 A R_{b}
$$

The final form of electric power generation from a tidal barrage according the following operation patterns are:-

- For one way generation turbine (two ebb tide)

$$
E P=2 \times 0.1125 N A R_{b}^{2}=0.225 N A R_{b}^{2}
$$

- For two way generation turbine (two ebb \& two flood tide)

$$
E P=4 \times 0.1125 N A R_{b}^{2}=0.45 N A R_{o}^{2}
$$


International Journal of Advances in Scientific Research and Engineering (ijasre), Vol 5 (7), July-2019

\section{RESULTS AND DISCUSSION}

\subsection{PDF model for Um Qasr Tide}

Figure 8 shows the PDF model of high tide. The lowest and highest high tide was 4.0 and $5.4 \mathrm{~m}$ with probability was $1.1 \%$ and $2.5 \%$, respectively. The most likely high tide was $4.8 \mathrm{~m}$ with probability was $29.6 \%$. Whereas, Figure 9 shows the PDF model of low tide. The lowest and highest low tide was 0.2 and $1.8 \mathrm{~m}$ with probability was $3.0 \%$ and $0.8 \%$, respectively. The most likely low tide was $1.2 \mathrm{~m}$ with probability was $22.74 \%$.

Table 1 was presented the average monthly of high and low tide. The highest average monthly of high tide was $4.78 \mathrm{~m}$ in July and the lowest one was $4.10 \mathrm{~m}$ in February. Whereas, the highest average monthly of low tide was $1.12 \mathrm{~m}$ in August and the lowest one was $0.75 \mathrm{~m}$ in January. Finally, the average high and low tide throughout the year was $4.56 \mathrm{~m}$ and $0.92 \mathrm{~m}$, respectively.

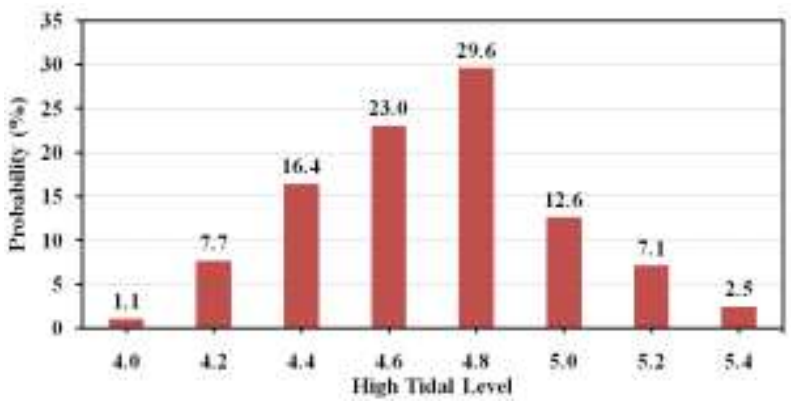

Figure 8: PDF model of high tide in Um Qasr.

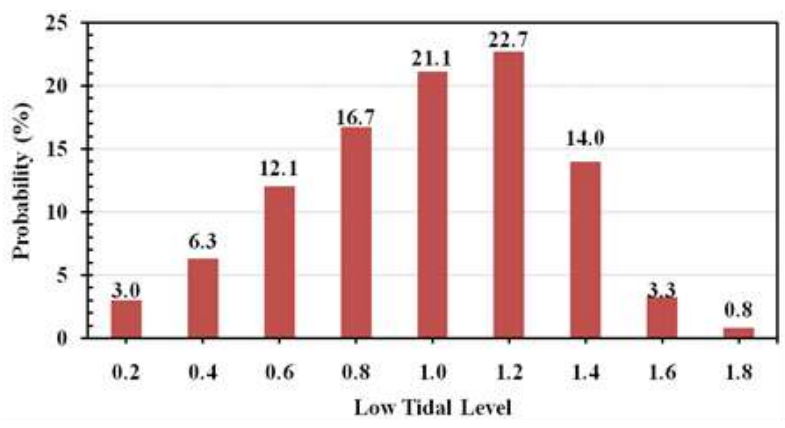

Figure 9: PDF model of low tide in Um Qasr.

Table 1: Monthly Average High and Low Tide for Um Qasr and Al-Faw

\begin{tabular}{|c|c|c|c|c|}
\hline & \multicolumn{2}{|c|}{ Average High Tide (m) } & \multicolumn{2}{c|}{ Average Low Tide (m) } \\
\hline Month & Um Qasr & Al-Faw & Um Qasr & Al-Faw \\
\hline Jan. & 4.63 & 2.92 & 0.75 & 0.25 \\
\hline Feb. & 4.10 & 2.57 & 0.80 & 0.34 \\
\hline Mar. & 4.51 & 2.82 & 0.95 & 0.45 \\
\hline Apr. & 4.41 & 2.76 & 0.89 & 0.42 \\
\hline May & 4.68 & 2.98 & 0.85 & 0.37 \\
\hline Jun. & 4.61 & 2.97 & 0.85 & 0.39 \\
\hline Jul. & 4.78 & 3.08 & 0.99 & 0.52 \\
\hline Aug. & 4.73 & 3.03 & 1.12 & 0.62 \\
\hline Sept. & 4.50 & 2.85 & 1.08 & 0.60 \\
\hline Oct. & 4.59 & 2.91 & 1.04 & 0.54 \\
\hline Nov. & 4.52 & 2.88 & 0.86 & 0.38 \\
\hline Dec. & 4.69 & 2.99 & 0.79 & 0.29 \\
\hline Average of year & 4.56 & 2.90 & 0.92 & 0.43 \\
\hline
\end{tabular}

\subsection{PDF Model for Al-Faw Tide}

Figure 10 shows the PDF model of high tide. The lowest and highest high tide was 2.4 and $3.8 \mathrm{~m}$ with probability was $4.4 \%$ and $0.5 \%$, respectively. The most likely high tide was $3.0 \mathrm{~m}$ with probability was $25.8 \%$. Whereas, Figure 11 shows the PDF model of 
low tide. The lowest and highest low tide was -0.4 and $1.2 \mathrm{~m}$ with probability was $0.8 \%$ and $1.6 \%$, respectively. The most likely low tide was $0.6 \mathrm{~m}$ with probability was $21.9 \%$.

Table 1 was presented the average monthly of high and low tide. The highest average monthly of high tide was $3.08 \mathrm{~m}$ in July and the lowest one was $2.57 \mathrm{~m}$ in February. Whereas, the highest average monthly of low tide was $0.62 \mathrm{~m}$ in August and the lowest one was $0.25 \mathrm{~m}$ in January. Finally, the average high and low tide throughout the year was $2.90 \mathrm{~m}$ and $0.43 \mathrm{~m}$, respectively.

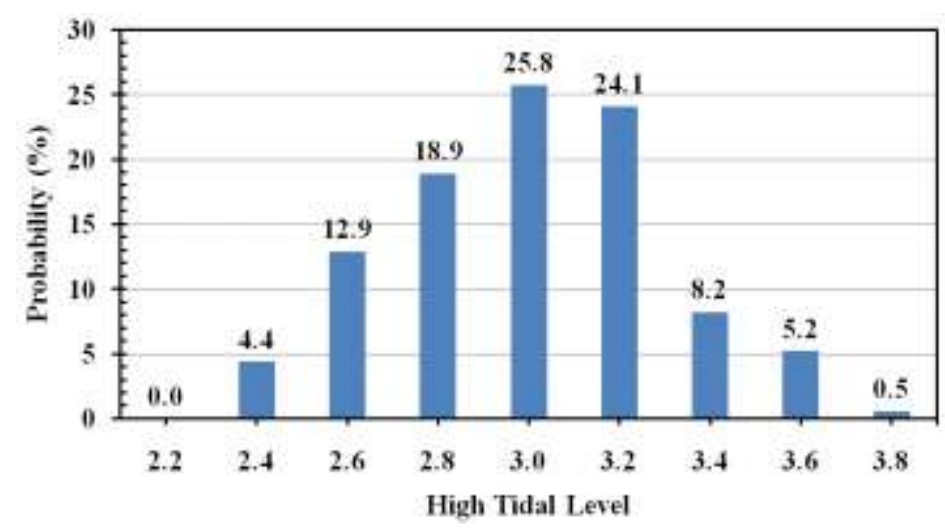

Figure 10: PDF model of high tide in Al-Faw.

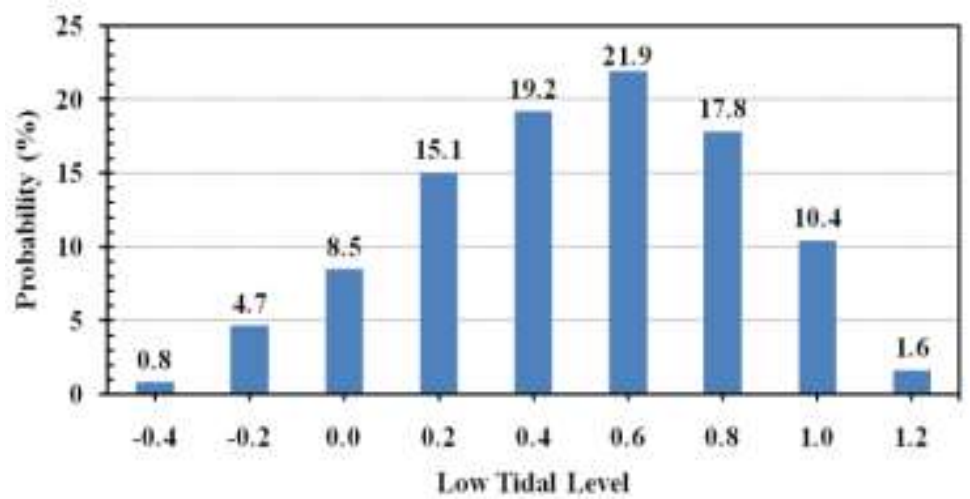

Figure 11: PDF model of low tide in Al-Faw.

\subsection{Tidal Power Density}

In this part of the paper it will deal with the calculation of the potential tidal power density of Um Qasr and Al-Faw to investigate the best site for construction a tidal power station to generate electricity. Eq. (9) will be used in the next analysis because of the prevailing situation in the coastal area of Basra is semidiurnal tide.

Figure 12 shows the tidal power density was fluctuated with the tidal range in Um Qasr and Al-Faw. From Table 2, the Maximum and minimum tidal power density of Um Qasr were 24.34 and $6.56 \mathrm{MW} / \mathrm{km}$ which occurred on date 21/1 and 25/6, respectively. So, the average tidal power density in Um Qasr was $12.73 \mathrm{MW} / \mathrm{km}$. whereas, The Maximum and minimum tidal power density of Al-Faw were 14.4 and 2.03 MW/km which occurred on date 21/1 and 25/6, respectively. So, the average tidal power density in Um Qasr was $5.99 \mathrm{MW} / \mathrm{km}$. It is also clear that the values of tidal power in Um Qasr are higher than Al-Faw because the tidal range in Um Qasr is higher than that of Al-Faw. Moreover, it was concluded that the tidal power of Um Qasr was more than twice Al-Faw.

Figure 13 shows the total monthly tidal power density of Um Qasr and Faw. It were changed from month to month according to the tidal range. From Table 2, the Maximum and minimum of total monthly tidal power density was occurred December and September. The Maximum and minimum of total monthly tidal power density in Um Qasr was 435.07 and $338.85 \mathrm{MW} / \mathrm{km}$, respectively. Whereas, the Maximum and minimum of total monthly tidal power density in Al-Faw was 215.14 and 149.20MW/km, respectively. However, the total annual tidal power density in Um Qasr and Al-Faw was 4646.82 and 2185.63 MW/km, respectively. Moreover, it was concluded that the tidal power of Um Qasr was more than twice Al-Faw. 


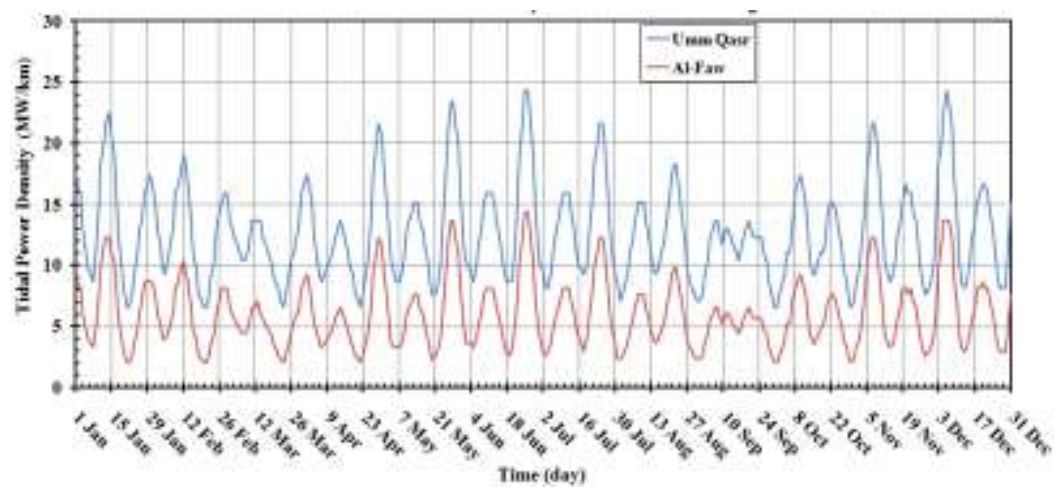

Figure 12: Daily tidal power density (TPD) in Um Qasr and Al-Faw.

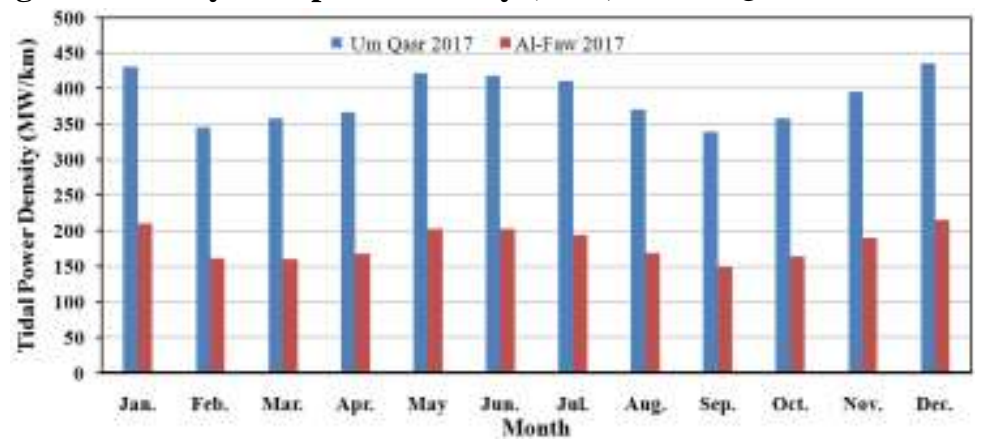

Figure 13: Monthly tidal density (TPD) in Um Qasr and Al-Faw.

Table 2: Daily, Monthly and Annual Tidal Power Density in Um Qasr and Al-Faw

\begin{tabular}{|c|c|c|c|c|}
\hline \multirow{2}{*}{ TPD (MW/km) } & \multicolumn{2}{|c|}{ Site } & \multirow{2}{*}{ Date } \\
\cline { 2 - 4 } & Um Qasr & Al-Faw & \\
\hline \multirow{3}{*}{ Daily } & Max. & 24.34 & 14.4 & Jan. 1, 2017 \\
\cline { 2 - 5 } & Min. & 6.561 & 2.025 & Jun. 25, 2017 \\
\cline { 2 - 5 } & Average & 12.73 & 5.99 & - \\
\hline \multirow{2}{*}{ Monthly } & Max. & 435.07 & 215.14 & Dec. 2017 \\
\cline { 2 - 5 } & Min. & 338.85 & 149.2 & Sep. 2017 \\
\hline \multicolumn{2}{|c|}{ Annual } & 4646.82 & 2185.63 & 2017 \\
\hline
\end{tabular}

\subsection{Electrical Power of Um Qasr Tidal Barrage}

In this study, the Umm Qasr barrage was proposed to establish at its site and boundaries drawn on the map which shown in Fig. 14. The results of PDF model for Um Qasr were explained that the average high and low tide throughout the year was 4.56 and $0.92 \mathrm{~m}$, respectively. So, the turbine will be placed at a level $0.92 \mathrm{~m}$ with tidal range $3.64 \mathrm{~m}$ and minimum head $1.02 \mathrm{~m}(0.28 \mathrm{R})$. Therefore, the dischargeable head or the basin range $(\mathrm{Rb})$ is $2.62 \mathrm{~m}$ and turbine running time is $0.65 \times 6.2 \approx 4$ hour. The number of turbine and total output electric power were calculated for different surface area of basin tidal barrage as listed in Table 3 . The electric power (EP) and the number of turbines $(\mathrm{N})$ were increased with increasing the surface area of the basin. However, the electric power in the two-way generation is twice that of the one-way generation. Moreover, If the basin surface area was $4 \mathrm{~km} 2$, it will need 16 turbines to generate an estimated electric power of 98.85 and 197.69MW in the case of one way and two way generation, respectively. While as doubling the basin surface area to $8 \mathrm{~km} 2$ will be required 32 turbines to generate an estimated electric power of 395.39 and $790.78 \mathrm{MW}$ in the case of one way and two way generation, respectively. This means doubling the basin surface area lead to double the turbines number by twice and double the electric power by four times. 


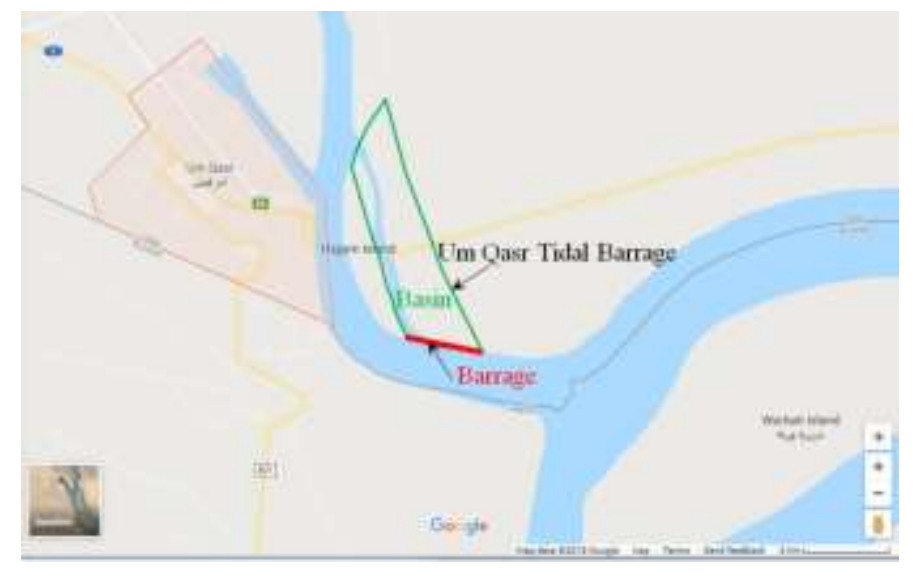

Figure 14: Proposed a Tidal Barrage location at Um Qasr site.

Table 3: One way and Two Way Electric Generation Power of Um Qasr Barrage for various Basin Surface Area and Turbine number

\begin{tabular}{|c|c|c|c|c|c|}
\hline \multirow{2}{*}{$\mathbf{A}\left(\mathbf{k m}^{\mathbf{2}}\right)$} & \multirow{2}{*}{$\mathbf{N}$} & \multicolumn{2}{|c|}{ One-way Generation } & \multicolumn{2}{c|}{ Two-way Generation } \\
\cline { 3 - 6 } & & $\mathbf{E P}(\mathbf{M W})$ & RMED (\%) & EP $(\mathbf{M W})$ & RMED (\%) \\
\hline 1 & 4 & 6.18 & 0.41 & 12.36 & 0.82 \\
\hline 2 & 8 & 24.71 & 1.65 & 49.42 & 3.29 \\
\hline 3 & 12 & 55.60 & 3.71 & 111.20 & 7.41 \\
\hline 4 & 16 & 98.85 & 6.59 & 197.69 & 13.18 \\
\hline 5 & 20 & 154.45 & 10.30 & 308.90 & 20.59 \\
\hline 6 & 24 & 222.41 & 14.83 & 444.81 & 29.65 \\
\hline 7 & 28 & 302.72 & 20.18 & 605.44 & 40.36 \\
\hline 8 & 32 & 395.39 & 26.36 & 790.78 & 52.72 \\
\hline 9 & 36 & 500.41 & 33.36 & 1000.83 & 66.72 \\
\hline 10 & 40 & 617.80 & 41.19 & 1235.59 & 82.37 \\
\hline
\end{tabular}

\subsection{Electrical Power of Al-Faw Tidal Lagoon}

The tidal lagoon is similar to the tidal barrage through using tides to generate electricity. In fact, the only real difference between the two is that the tidal lagoon does not block off an entire estuary, but rather makes use of only part of it. As well as, Tidal barrage using a natural basin while the tidal lagoon using an artificial basin Surrounded by seawalls. Figure15 shows an outline for tidal barrage, tidal onshore lagoon and offshore lagoon [28].

In this study, the Al-Faw tidal lagoon was proposed to establish at its site and boundaries drawn on the map which shown in Fig. 16.

The results of PDF model for Al-Faw were explained that the average high and low tide throughout the year was 2.90 and $0.43 \mathrm{~m}$, respectively. So, the turbine will be placed at a level $0.43 \mathrm{~m}$ with tidal range $2.47 \mathrm{~m}$ and minimum head $0.69 \mathrm{~m}(0.28 \mathrm{R})$. Therefore, the dischargeable head or the basin range $(\mathrm{Rb})$ is $1.78 \mathrm{~m}$ and turbine running time is $0.65 \times 6.2 \approx 4$ hour. The number of turbine and the total output electric power were calculated for different surface area of basin tidal barrage as listed in Table 4 . The electric power (EP) and the number of turbines $(\mathrm{N})$ required were increased with increasing the surface area of the basin. However, the electric power in the two-way generation is twice that of the one-way generation. Moreover, if the basin surface area was $4 \mathrm{~km} 2$, it will need 11 turbines to generate an estimated electric power of 31.37 and $62.73 \mathrm{MW}$ in the case of one way and two way generation, respectively. While as doubling the basin surface area to $8 \mathrm{~km}^{2}$ will be required 22 turbines to generate an estimated electric power of 125.47 and $250.94 \mathrm{MW}$ in the case of one way and two way generation, respectively. This means doubling the basin surface area lead to double the turbines number by twice and double the electric power by four times.

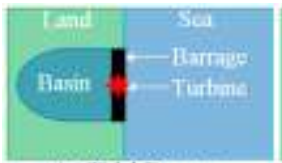

(a) Tidal Barrage

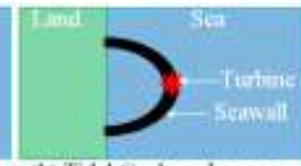

(b) Tidal Onstore Lagoon

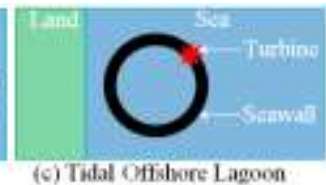

(c) Tidal offsbore Lagoon

Figure 15: Tidal Barrage and types of Tidal Lagoon. 


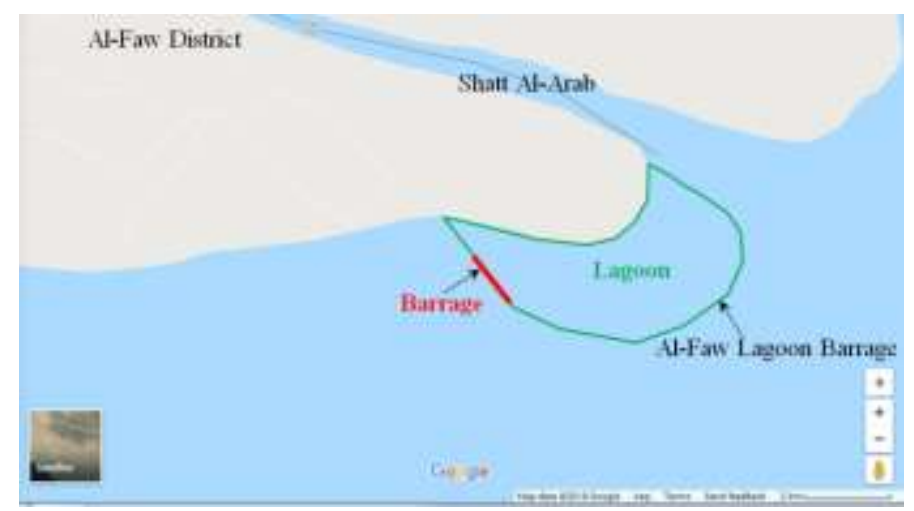

Figure 16: Proposed a Tidal Lagoon location at Al-Faw site.

Table 4: One way and Two Way Electric Generation Power of Al-Faw lagoon for various Basin Surface Area and Turbine number

\begin{tabular}{|c|c|c|c|c|c|}
\hline \multirow{2}{*}{$\mathbf{A}\left(\mathbf{k m}^{\mathbf{2}}\right)$} & \multirow{2}{*}{$\mathbf{N}$} & \multicolumn{2}{|c|}{ One-way Generation } & \multicolumn{2}{c|}{ Two-way Generation } \\
\cline { 3 - 6 } & & $\mathbf{E P}(\mathbf{M W})$ & RMED $(\boldsymbol{\%})$ & $\mathbf{E P}(\mathbf{M W})$ & RMED (\%) \\
\hline 1 & 3 & 2.14 & 0.14 & 4.28 & 0.29 \\
\hline 2 & 6 & 8.55 & 0.57 & 17.11 & 1.14 \\
\hline 3 & 9 & 19.25 & 1.28 & 38.50 & 2.57 \\
\hline 4 & 11 & 31.37 & 2.09 & 62.73 & 4.18 \\
\hline 5 & 14 & 49.90 & 3.33 & 99.80 & 6.65 \\
\hline 6 & 17 & 72.71 & 4.85 & 145.43 & 9.70 \\
\hline 7 & 19 & 94.81 & 6.32 & 189.63 & 12.64 \\
\hline 8 & 22 & 125.47 & 8.36 & 250.94 & 16.73 \\
\hline 9 & 25 & 160.40 & 10.69 & 320.80 & 21.39 \\
\hline 10 & 27 & 192.48 & 12.83 & 384.96 & 25.66 \\
\hline
\end{tabular}

\subsection{Electricity Supply Ratio}

Electricity Supply Ratio (ESR) is the percentage of the electricity supply to electricity demand, i.e.,

$$
\text { Electricity Supply Ratio }=\frac{\text { Supply }}{\text { Demand }} \times 100
$$

The average electrical demand of Basra governorate which is around 1500MW in 2017 [1]. So, Electricity Supply Ratio was calculated for Um Qasr and Al-Faw site as listed in Table 3 and 4, respectively. Furthermore, the values of the two tables were plotted in Fig. 17. From these tables it is clear that the Electricity Supply Ratio increases with increasing the basin surface area.

Electricity Supply Ratio from Um Qasr tidal barrage with $4 \mathrm{~km}^{2}$ basin surface area was 6.59 and $13.18 \%$ of Basra electricity demand in the case of one way and two way generation, respectively. While, Electricity Supply Ratio from Um Qasr tidal barrage with $8 \mathrm{~km}^{2}$ basin surface area was 26.36 and $52.72 \%$ of Basra electricity demand in the case of one way and two way generation, respectively. It was concluded that doubling the basin surface area lead to double the Electricity Supply Ratio by four times. Electricity Supply Ratio from Al-Faw tidal lagoon with $4 \mathrm{~km}^{2}$ basin surface area was 2.09 and $4.18 \%$ of Basra electricity demand in the case of one way and two way generation, respectively. While, Electricity Supply Ratio from Al-Faw tidal lagoon with $8 \mathrm{~km}^{2}$ basin surface area was 8.36 and $16.73 \%$ of Basra electricity demand in the case of one way and two way generation, respectively. It was also concluded that doubling the basin surface area lead to double the Electricity Supply Ratio by four times. 


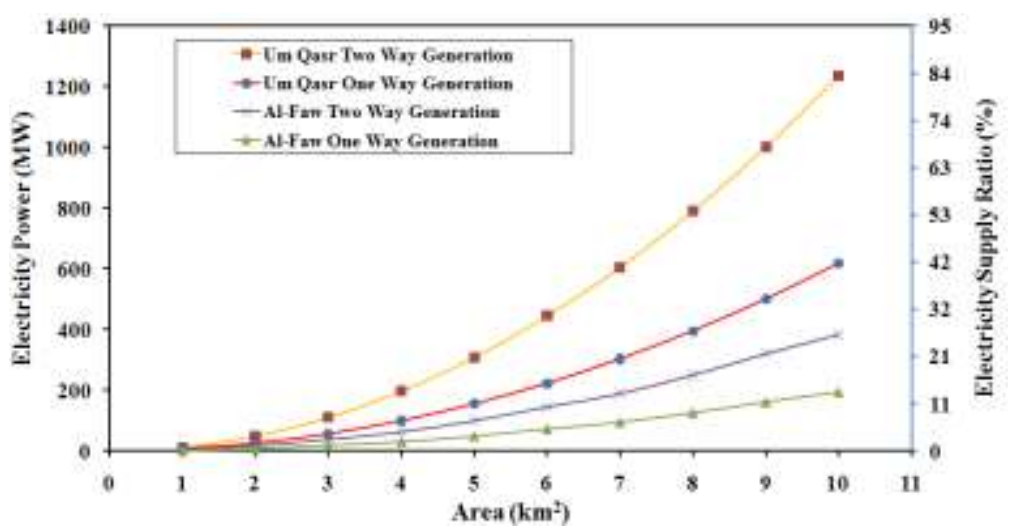

Figure 17: Electricity Power and Electricity Supply Ratio for One-way and Two-way generation from Um Qasr and Al-Faw.

\section{CONCLUSION}

Based on assumptions and limitations of the present study, the following outlines of conclusions could be drawn for each site of Iraqi coastal region:

Um Qasr

- The high tide ranged from 4 to $5.4 \mathrm{~m}$ and prevail high tide was $4.9 \mathrm{~m}$.

- The low tide ranged from 0.2 to $1.8 \mathrm{~m}$ and prevail low tide was $1.3 \mathrm{~m}$

- The average high and low tide throughout the year was $4.56 \mathrm{~m}$ and $0.92 \mathrm{~m}$, respectively. So, the tidal range was $3.64 \mathrm{~m}$

- Maximum and minimum tidal power density were 24.34 and $6.56 \mathrm{MW} / \mathrm{km}$, respectively. However, the average tidal power density was $12.73 \mathrm{MW} / \mathrm{km}$.

- As barrage has a basin surface area of $4 \mathrm{~km}^{2}$, it will need 16 turbines to provide an estimated electric power of 98.85 and 197.69MW with Electricity Supply Ratio was 6.59 and $13.18 \%$ of Basra electricity demand in the case of one way and two way generation, respectively.

Al-Faw

- The high tide ranged from 2.4 to $3.8 \mathrm{~m}$ and prevail high tide was $3.1 \mathrm{~m}$.

- The low tide ranged from -0.4 to $1.2 \mathrm{~m}$ and prevail low tide was $0.7 \mathrm{~m}$

- The average high and low tide throughout the year was $2.90 \mathrm{~m}$ and $0.43 \mathrm{~m}$, respectively. So, the tidal range was $2.46 \mathrm{~m}$

- Maximum and minimum tidal power density were 14.4 and $2.03 \mathrm{MW} / \mathrm{km}$, respectively. However, the average tidal power density was $5.99 \mathrm{MW} / \mathrm{km}$.

- As Lagoon has a basin surface area of $4 \mathrm{~km} 2$, it will need 11 turbines to provide an estimated electric power of 31.37 and 62.73MW with Electricity Supply Ratio was 2.09 and $4.18 \%$ of Basra electricity demand in the case of one way and two way generation, respectively.

From the above point, it is also clear that the tidal power in Um Qasr was higher more than twice Al-Faw. Therefore, the electric power from Um Qasr Barrage was higher more than three time that of Al-Faw lagoon. Coastal regions of Iraq, particularly Um Qasr site is most approving locations for tidal power generation due to has a highest tidal range (>3.5m).

\section{REFERENCES}

[1] Iraqi Central Statistical Organization (ICSO). Iraqi Ministry of Planning, "Annual Statistical Abstract 2017”, (2017), available online: http://cosit.gov.iq/AAS2017/Annual\%20Abstract\%20of\%20Statistic\%20_2017.pdf

[2] Iraqi Ministry of Electricity (IME), "Iraq Electricity Master Plan”, Parsons Brinckerhoff, New York, USA, Executive Summary Final Report, (2010), available online: http://www.iraq-jccme.jp/pdf/archives/electricity-master-plan.pdf

[3] L. Khatteeb and I. Harry, "Turn a light on: electricity sector reform in Iraq”, Brookings Institution, Brookings Doha Center, Doha, Qatar, 2015, available online: https://www.brookings.edu/wp-content/uploads/2016/06/Alkhatteeb-IstepanianEnglish-PDF.pdf

[4] T. N. Veziroğlu and S. Şahi, “21st Century’s energy: Hydrogen energy system”, Energy conversion and management, Vol. 49, No. 7, pp. 1820-1831, 2008.

[5] I. Dincer, "Renewable energy and sustainable development: a crucial review", Renewable and Sustainable Energy Reviews, Vol. 4, No. 2, pp. 157-175, 2000.

[6] N. H. Samrat, N. Mamun, S. M. Uddin and A. Islam, "Case study: Tidal current energy potential in Bangladesh", 2013 International Conference on Informatics, Electronics and Vision (ICIEV 2013), Dhaka, Bangladesh, May 2013, pp. 1-5, 
[7] J. Widén, N. Carpman, V. Castellucci, D. Lingfors, J. Olauson, F. Remouit, M. Bergkvist, M. Grabbe and R. Waters, "Variability assessment and forecasting of renewables: A review for solar, wind, wave and tidal resources", Renewable and Sustainable Energy Reviews, Vol. 1, No. 44, pp. 356-75, 2015

[8] Federal Research Division, "Country Profile: Iraq", United States Library of Congress, USA, 2006, available online: https://www.loc.gov/rr/frd/cs/profiles/Iraq.pdf

[9] R. Burrows, I. A. Walkington, N. C. Yates, T. S. Hedges, J. Wolf and J. Holt, "The tidal range energy potential of the West Coast of the United Kingdom", Applied Ocean Research, Vol. 31, No. 4, pp. 229-238, 2009

[10] Y.H. Bae, K.O. Kim and B.H. Choi, "Lake Sihwa tidal power plant project", Ocean Engineering, Vol. 37, No. 5-6, pp. 454-463, 2010.

[11] J. Xia, R. A. Falconer, B. Lin and G. Tan, "Estimation of annual energy output from a tidal barrage using two different methods", Applied Energy, Vol. 93, pp. 327-336, 2012.

[12] N. A. Husain, S. S. Abdullah and A. A. Al-Mahdi, "Some Features of the Physical Oceanography in Iraqi Marine Waters", Mesopotamian Journal of Marine Science, Vol. 24, No. 1, pp. 13-24, 2009.

[13] Joe Payne, "Tide Table and Solunar Charts For Iraq", Solunar Services LLC, Florida, USA, 2017, available online: http://www.solunarforecast.com/solunarcalendar.aspx or https://tides4fishing.com/as/iraq

[14] Dickman, S. R. "Dynamic ocean-tide effects on Earth's rotation”, Geophysical Journal International, Vol. 112, No. 3, pp. 448-470, 1993.

[15] D. J. Webb, “Tides and tidal energy”, Contemporary Physics, Vol. 23, No. 5, pp. 419-442, 1982.

[16] D. Pugh and P. Woodworth, Sea-level science: understanding tides, surges, tsunamis and mean sea-level changes, Cambridge University Press; Cambridge, UK, p. 395, 2014

[17] S. Pond and G. L. Pickard, Introductory dynamical oceanography, Elsevier, Butterworth-Heinemann, Vancouver, Canada, p. 349, 2013.

[18] R. D. Ray, D. J. Steinberg, B. F. Chao and D. E. Cartwright, "Diurnal and semidiurnal variations in the Earth's rotation rate induced by oceanic tides", Science, Vol. 264, No. 5160, pp. 830-832, 1994.

[19] N. J. Nidzieko, "Tidal asymmetry in estuaries with mixed semidiurnal/diurnal tides", Journal of Geophysical Research: Oceans, Vol. 115, No. C8, 2010.

[20] D. Prandle, Tides in estuaries and embayments, Tidal hydrodynamics, Ch. 7, 1st ed., Birkenhead, UK, John Wiley \& Sons, pp. 125-152, 1991.

[21] J. J. Shu, "Prediction and analysis of tides and tidal currents", The International hydrographic review, Vol. 4, No. 2, pp. 57-64, 2003.

[22] M. Salequzzaman, P. Newman, M. Ellery and B. Corry, "Prospects of electricity from tidal power in coastal regions of Bangladesh”, Journals of Bangladesh Studies, Vol. 1, No. 6, pp. 52-61, 2000.

[23] J. Wolf, I. A. Walkington, J. Holt and R. Burrows, "Environmental impacts of tidal power schemes", In Proceedings of the Institution of Civil Engineers-Maritime Engineering. Thomas Telford Publishing, Vol. 162, No. 4, pp. 165-177, 2009

[24] D. Prandle, "Design of tidal barrage power schemes", In Proceedings of the Institution of Civil Engineers-Maritime Engineering. Thomas Telford Ltd., Vol. 162, No. 4, pp. 147-153, 2009.

[25] V. H. Jerome, "Feasibility Study on Tidal Power Barrages. Including general plant design and site selection", Final report, Delta Marine Consultants, 2007.

[26] J. W. Tester, E. M. Drake, M. J. Driscoll, M. W. Golay and W. A. Peters, Sustainable energy: choosing among options, 2nd edition, MIT press, pp. 1056, 2012.

[27] K. A. Samo, A. R. H. Rigit, I. A. Samo and A. A. Shah, "Suitable Powerhouse Design for Kuching Barrage Tidal Power Scheme”, International Journal of Engineering Sciences \& Research Technology, Vol. 6, No. 9, pp. 154-172, 2017.

[28] G. Todeschini, "Review of tidal lagoon technology and opportunities for integration within the UK energy system", Inventions, Vol. 2, No. 3, pp. 14, 2017. 